\title{
The Relationship Between Anxiety and Academic Performance of Postgraduate International Students in a British University: A Cross-Sectional Quantitative Design
}

\author{
Dorcas Ibukun Adeoye-Agboola, Hala Evans \\ Health and Social Sciences, Institute for Health Research, University of Bedfordshire, Luton, UK
}

Email address:

dorcas.adeoye@study.beds.ac.uk (D. I. Adeoye-Agboola), Hala.Evans@beds.ac.uk (H. Evans)

To cite this article:

Dorcas Ibukun Adeoye-Agboola, Hala Evans. The Relationship Between Anxiety and Academic Performance of Postgraduate International Students in a British University: A Cross-Sectional Quantitative Design. Science Journal of Public Health. Vol. 3, No. 3, 2015 , pp. $331-338$. doi: $10.11648 /$ j.sjph.20150303.15

\begin{abstract}
Aims: Anxiety has a great effect on students' academic performance, especially among international students. Acculturation, discrimination, familiarity with the education system, weather, social support, and language limitation are among the main factors which contribute to anxiety among international students. This small scale study assesses the relationship between anxiety and academic performance of international students among postgraduate international students of in the University of Bedfordshire. A cross-sectional questionnaire survey was carried out. A non-randomised purposive sampling of $n=105$ postgraduate international students participated in the survey comprising of 66 male, 39 female. The findings indicate that anxiety is significantly correlated to academic performance. Workload, choice of coping with stress, future prospect, and change in the system of education are the major types of anxiety affecting our participants giving significant relationship when cross-tabulated with gender and/ ethnicity. Also in the aspect of difficulties in focusing on their studies, more than $50 \%$ disagree showing a significant relationship when compared with gender. Anxiety is seen as a tool to explain academic performance. Hence, it is important that this is considered to make their learning experience more fulfilling.
\end{abstract}

Keywords: Anxiety, Mental Health, Academic Performance, International Students, postgraduate, United Kingdom

\section{Introduction}

Over the years, the number of UK international students' increases which might contributes to the British economy and the international status of the British universities. Evidence shows that there are more than 3 million students studying in another country especially, in Western universities [1]. International students come into Britain to gain knowledge, improve their skills, receive internationally recognised degrees, and experience a different educational system. Some are self-sponsored while others are sponsored by either their governments or nongovernmental organisation. International students are important financial assets that contribute about \$19billion (U.S. dollars) yearly to U.S and Australian economy, and \$14billion to the UK economy [2].

There were more than 3.3 million international students studying in tertiary institution worldwide [1]; $19 \%$ in U.S.A, $10 \%$ in the UK, $7 \%$ in Germany, $7 \%$ in France and $7 \%$ in Australia; and some other countries like Canada, Japan, Russia have significant number of international students $[3,4]$.
One major reason for massive movement of international students into the UK is the limited opportunities and limited access to higher education, also good reputation of British education in their home countries [5]. The international students in turn enrich their chosen countries with their different cultural beliefs and perspectives [6]. It was argues that china has the greatest number of students in the UK which makes them the biggest contributor to the UK's economy [6]. International students are involved in a wide range of knowledge and skills of various disciplines, and also contribute to the workforce of their host country [2]. It is seen as a mutual benefit whereby international students gain academic achievement in their host country and they also bring financial and other cultural contributions to the host country.

Many students are faced with serious challenges such as environment, culture, food, language, educational system, weather and discrimination. All these challenging factors accumulate to pose anxiety on the international students. Some students find it hard to overcome these obstacles which 
increase their level of stress and anxiety. Acculturative stress is defined as the stress that occurs due to life changes; this however can lead to anxiety that can affect their integration [8].

These studies $[9,10]$ grouped anxiety as either trait or state anxiety; trait anxiety related to the individual characteristics, whereas state anxiety triggered by some environmental conditions such as examination. An anxious person experience physical feelings and worrying thoughts which makes it difficult to do normal daily activities. Symptoms of anxiety involve being talkative, mixing words, and having irrational or unrealistic thoughts.

Anxiety shows a negative influence on students' learning outcomes and prevents students from learning a foreign language effectively [11-13]. Anxiety is experienced by everyone but the level of anxiety differ and common when an individual is trying to adapt to a new environment $[14,15]$. Nevertheless, it can be seen as a problem when is frequently experienced and happens in circumstances that does not pose stress $[16,17]$. One out of four individuals experience anxiety disorder during their lifetime [18]; however, when not treated, it is accompanied by physical symptoms such as muscle tension, irritability, sweating and headaches [16]. Studies have shown that anxiety is common among international students studying in foreign countries [2,17], and this may present a threat on their integration.

A national survey carried out by [19], funded by the UK Economic and Social Research Council, was based on a twoyear multi-method research project. It was reported that $32 \%$ that mixed with the Home students improved slightly during the first term compared with $29 \%$ that do not mixed with home students. It was also found that $60 \%$ of the participants agreed that the UK was a comfortable environment, including $12 \%$ showing a very strong agreement of a friendly environment. Due to the increase number of international students, administrators and academics are developing means of helping international students to adapt to their newly found environment and gain their experiences as students [20].

This paper therefore discusses the impact of anxiety on international students, the way to integrate students and cater for their needs. Thus, this study will enable higher institutions to provide or improve on their support services to help students prevent any form of anxiety that may affect their better learning outcomes.

\section{Methods}

\subsection{Research Design}

A descriptive cross-sectional quantitative method was used for data collection with the purpose of understanding the relationship between the variables such as gender, ethnicity over level of anxiety using the survey method of inquiry.

\subsection{Sampling Method}

The researcher collects information using self- administered questionnaire from a population of interest such as international postgraduate students studying at the University of Bedfordshire, Luton-UK. Considering the statistics of international students in the University of Bedfordshire, International students are nearly 4,000 in population. Therefore, a population of 131 students in the University of Bedfordshire, UK were targeted with the expectation of having more than $80 \%$ response rate of the target.

\subsection{Data Collection Tool}

A non-randomised purposive sampling self-administered questionnaire was used because it will be possible to ask questions on the level of anxiety and how this is affecting their academic performance. The questionnaire design was valid, reliable, simple, clear, and comprehensive and contained demographic information like gender, age range, knowledge of language, relating to anxiety. The questionnaire contains closed questions with few open questions.

\subsection{Structure of the Questionnaire}

The collection tool was designed to meet the aims and objectives of the study. The questionnaire was divided into various sections which were discussed below, however, the first section was categorised as an independent variable that is unchangeable and in which other sections depend on it (dependent variables). The demography information was the first section; an important characteristic of a population in which survey is based on. The characteristics are age, marital status, gender, occupation, and ethnicity. These characteristics stand as an independent variable that cannot change and thus, other variables depend on it (dependent variables). Section 2 tests on their lived experience while studying and what causes anxiety at initial stage. It asked about the aspect of tasks, activities, or skills that make students feel more anxious with the option of whether listening, speaking, reading or writing. It further seeks to know if the number of modules, inadequate library facilities or change in weather does increase chance of anxiety. More questions were on how paid/unpaid employment can have a great impact on academic performance and as well increase anxiety. Section 3 forms students and their learning experience; a closed question using scales to know the degree of anxiety. This was applied containing five possible responses: strongly agree, agree, neither agree or disagree, disagree, strongly disagree. The questions were short, simple and easy to understand testing what can initiate anxiety in learning experiences. Section 4 measures students and their coursework while Section 5 shows relationship between social life and decreased anxiety. It is assumed that social life may contribute a great deal in limiting anxiety that is affecting better academic performance.

\subsection{Data Collection}

The data was collected between May and June, 2013. This was done by booking an appointment with various lecturers 
with an approval to speak to postgraduate students about the study; this strategy of lecturers' approval supports high response rate. Another way was to visit communication skill classes where a larger number of international students were found. A formal ethical permission was given by the ethics committee of University of Bedfordshire via the Institute for Health Research. In addition, an informed consent form was given to each participant as a written agreement document to support their decision to participate in the research with verbal explanation for clarity sake and participants' information sheet. At the time of analysis, 105 questionnaires $(\mathrm{n}=105)$ administered during the survey were coded and analysed using SPSS software version 19.

\section{Results}

Out of 131 total numbers of questionnaires produced for the survey, 105 questionnaires were completed and returned to the researcher giving a response rate of $80 \% ; 17$ questionnaires were not returned giving the rate $13 \%$ and 9 questionnaires were returned unanswered giving a rate of $7 \%$. However, the 17 questionnaires unreturned and 9 questionnaires returned and unanswered were not included in the analysis; 105 questionnaires completed and returned were analysed and represent a 100\% for this research finding.

\subsection{Participants' Demographics}

The findings showed $63 \%$ were male, $36 \%$ female and $1 \%$ respondent did not indicate any gender; their mean (SD) age was 26.18 (3.63) years (range 17-42 year) with most prevalent ages being $26-32$ years $(61 \%)$. Twelve different countries were represented and all fell into the category of either African or South Asian with $45.7 \%$ and $54.3 \%$ respectively (see Table 1). Countries categorized as South Asia are Pakistan, China, Sri lanka, India, Nepal, Bangladesh, Afghanistan; and countries categorized as Black Africa/Caribbean are Nigeria, Ghana, Jamaica, Uganda, Tanzania. Majority of the international students are full time students and not part time students. In addition, $63.8 \%$ of the participants studied Business related courses, 30.5\% Health related courses, and 2.9\% Information Technology, $1.9 \%$ Natural sciences and Art option was 1\%. Majority were living in a private accommodation with friends having $48.6 \%$, $30.2 \%$ private alone, $15.2 \%$ University accommodation and few living in the UK with family. Higher percentage were singles $(78.1 \%), 20.0 \%$ were married, $1.9 \%$ living with partner and none indicated Divorced/separate nor widowed.

Table 1. Showing the demographics of Participants.

\begin{tabular}{|c|c|c|c|c|c|}
\hline & $\mathbf{N}$ & $\%$ & & $\mathbf{N}$ & $\%$ \\
\hline Age & & & \multicolumn{3}{|l|}{ Gender } \\
\hline $17-25$ & 37 & $35.2 \%$ & \multirow{4}{*}{$\begin{array}{l}\text { Male } \\
\text { Female } \\
\text { Missing }\end{array}$} & \multirow{4}{*}{$\begin{array}{l}66 \\
38 \\
1\end{array}$} & \multirow{4}{*}{$\begin{array}{l}62.9 \% \\
36.2 \% \\
1.0 \%\end{array}$} \\
\hline $26-33$ & 64 & $61.0 \%$ & & & \\
\hline $34-41$ & 3 & $2.9 \%$ & & & \\
\hline$>42$ & 1 & $1.0 \%$ & & & \\
\hline Ethnicity & \multirow{5}{*}{$\begin{array}{l}48 \\
57\end{array}$} & \multirow{5}{*}{$\begin{array}{l}45.7 \% \\
54.3 \%\end{array}$} & Course Studied & & \\
\hline \multirow{4}{*}{$\begin{array}{l}\text { Black } \\
\text { Asian }\end{array}$} & & & Health related & 32 & $30.5 \%$ \\
\hline & & & IT courses & 3 & $2.9 \%$ \\
\hline & & & Natural Sciences & 2 & $1.9 \%$ \\
\hline & & & Art options & 1 & $1.0 \%$ \\
\hline Accommodation & & & Marital Status & & \\
\hline University Accommodation & 16 & $15.2 \%$ & Single & 82 & $78.1 \%$ \\
\hline Private alone & 32 & $30.2 \%$ & Married & 21 & $20.0 \%$ \\
\hline Private acc. with friends & 51 & $48.6 \%$ & Living with partner & 2 & $1.9 \%$ \\
\hline
\end{tabular}

Table 2. Showing frequencies and percentages of variables that may increase level of stress.

\begin{tabular}{|c|c|c|c|c|c|c|c|c|c|c|}
\hline & \multirow{2}{*}{\multicolumn{2}{|c|}{ Exam Failure }} & \multirow{2}{*}{\multicolumn{2}{|c|}{ Resubmitting coursework }} & \multirow{2}{*}{\multicolumn{2}{|c|}{ Weather Anxiety }} & \multicolumn{4}{|c|}{ Employment status } \\
\hline & & & & & & & \multicolumn{2}{|c|}{ Paid Job } & \multicolumn{2}{|c|}{ Voluntary Job } \\
\hline & Freq. & Valid \% & Freq. & Valid \% & Freq. & Valid \% & Freq. & Valid \% & Freq. & Valid $\%$ \\
\hline Yes & 15 & $14 \%$ & 9 & $9 \%$ & 8 & $54 \%$ & 29 & $28 \%$ & 8 & $8 \%$ \\
\hline No & 90 & $86 \%$ & $96 \%$ & $91 \%$ & 97 & $45 \%$ & 74 & $70 \%$ & 97 & $92 \%$ \\
\hline Missing & 0 & $0 \%$ & 0 & $0 \%$ & 0 & $0 \%$ & 2 & $2 \%$ & 0 & $0 \%$ \\
\hline Total & 105 & 100 & 105 & 100 & 105 & $100 \%$ & 105 & $100 \%$ & 105 & $100 \%$ \\
\hline
\end{tabular}

Questions on factors that can increase level of stress were asked such as if they have failed an exam before; if they had resubmitted coursework before; if weather change had affected their study pattern; and on their employment status. It was also used to understand the types of anxiety experienced by international students and their degree of freedom.

\subsection{Exams and Assessments Anxiety}

Examination is one of the common concerns for students. Questions on if students prefer exams to easy/report was asked; more than average of respondents prefer exams to 
easy/reports. Also, ethnicity was compared with respondents' choice of assessments; $54 \%$ of African students prefer writing exams than easy/reports while Asians have $46 \%$. Question on if respondents have had a great deal of coursework, was cross-tabulated with ethnicity; it was not significant, however, measuring 'a great deal of coursework' which is dependent variable with gender which is the independent variable, chi-square test shows significant relationship ( $\mathrm{p}=0.01, \mathrm{df}=8)$; showing $63 \%$ in male, $36 \%$ in female and $1 \%$ for missing value.

\subsection{Financial Anxiety}

Financial stress can lead to anxiety among students, thus, it is important to know the impact employment may create in students' academic performance. A higher percentage of respondents were not employed compared to the counterparts (see table 2). However, respondents' ethnicity was compared with employment status; Asian respondents have slightly higher percentage in employment opportunities than African respondents but it is not significant. Impact of age on employment opportunity were considered, responders' age between 26-33 years has more job opportunities than the other responders; also Business students have the highest percentage in employment opportunity than other identified courses in this report (see table 1).

\subsection{Second Language Anxiety}

Table 3. shows students' skills against gender.

\begin{tabular}{lllll}
\hline Gender & Listening & Speaking & Reading & Writing \\
\hline Male & $78 \%$ & $65 \%$ & $75 \%$ & $51 \%$ \\
Female & $22 \%$ & $35 \%$ & $20 \%$ & $48 \%$ \\
Missing & $0 \%$ & $0 \%$ & $5 \%$ & $0 \%$ \\
Total & $100 \%$ & $100 \%$ & $100 \%$ & $100 \%$ \\
\hline
\end{tabular}

Learning English as a second language was recognized in this research as an important factor that contributes to anxiety among international students. Question was asked on the aspect of the tasks, activities, or skills that makes students feel anxious: 9\% listening; 32\% speaking; 19\% reading; 37\% writing; 3\% missing values. When impact of gender was measured on the students' skills: male respondents have higher score in listening, speaking and reading but 'writing' has a close score of $51 \%$ male and $48 \%$ females between this gender (see table 3); meaning language difficulty is relevant rather than gender.

\subsection{Weather Anxiety}

Weather anxiety, although not common in literatures, but could be one of the major factors affecting international students in the UK. Questions on change in weather affecting study pattern was asked; $54 \%$ of the respondents were seen to have been affected by weather and $46 \%$ respondents were not affected (see table 2). For those affected, further question was asked on how weather has affected their study pattern and was anonymously represented as follows: student A says 'It makes me feel sleepy and lazy when the weather is very cold; student B 'It is very difficult for me to go to the library and study and that affect my grade'; student C 'I cannot concentrate' and so on. It was also analysed if change in weather has impact on gender, ethnicity and age, although was not significant: $63 \%$ of males and $36 \%$ of females were affected, $1 \%$ was a missing value; also 53\% Asians were affected with change in weather while $47 \%$ Africans were affected which gives a small gap between two categories ethnicity.

\subsection{Library Facilities}

Of the total percentage of respondents, $88 \%$ were happy with the library facilities; $16 \%$ were quite unhappy and $1 \%$ was neither happy nor unhappy. This may mean the facilities including the materials needed for students to study were available. Moreover, different courses studied by students may have effect on materials available in the library, thus, effect of course studied was measured on the library materials but chi-square does not show significant relationship $(=0.99)$.

\subsection{Student Social life and Support Services}

Question on counselling services offered by the university was asked; more than half of the respondents were happy with the counselling team by the University. With stress experienced by the international students, question on what they do when stressed-up, was asked; $45 \%$ sleep, $31 \%$ hangout, $10 \%$ take a walk and $15 \%$ others identified watching movies, play games, go shopping, cook. When ethnicity was measured against what students' do when stressed-up, 90\% Asians prefer to take a walk while $55 \%$ of Black/Africans sleep.

\section{Career Aspiration}

Question on if students get frustrated in achieving their goals was asked, more than half of the respondents agree that it is a concern to them if they fail to achieve their goals (see figure 1). This question was also measured on how significant is gender on future prospects, chi-square test gives significant relationship that is, $p=0.01$ which is significant. It also shows that $61 \%$ of females of the total respondents strongly agree on frustration faced when goals were not achieved.

Considering the data given, workload, choice of coping with stress, career aspiration, and change in the system of education are the major types of anxiety affecting international students in this study giving significant relationship ( $p=0.01)$ when cross-tabulated with gender and/ ethnicity. Simply where an international student come from and gender difference can impact on the level of stress in a foreign country like the UK. There is a need for more awareness for universities on the anxiety affecting international students' experience and ways of improving their experiences. 


\section{Discussion}

Mental health of international students needs more attention seeing the advantage they contribute to the economy of the country. The stress experienced through adjusting to a new environment creates anxiety but it is multiplied among international students; which leads to acculturative stress [14].

Findings from this study have actually shown its relevance to public health, and especially international students studying in the UK. It is also not surprising that anxiety can affect international students on their academic performance through their finances, career aspiration and workload. Equally, the study is revealing that the environment and where students live contributes to the living experience of students in the UK. This is also supported by [10] that accommodation experience contributes to the experience of students outside their country. According to the result, $48 \%$ of students lived in a private accommodation with friends; these friends are usually from their country; $30.2 \%$ lives in a private accommodation alone. This may consequently slow down the rate at which students adapt to new environment unlike living with students from another country or with Home/local students. Adapting to a new environment is a relatively stable change which makes an individual to respond to external demand [8]. It is only $15.2 \%$ that lived in university accommodation that may contain different students from different countries; $5.7 \%$ of international students lived with families in the UK. This is comparable to the study from [21] that it is necessary for international students to live in a university accommodation, this helps with students' security; which gives government a more responsibility to ensure that the security of international students is taken with all seriousness. However, 15.2\% international students for this study may be guaranteed great security due to their living in university accommodation. The type of accommodation and where the students live during their study has effects on how easy it will be to adapt to their new environment. This implies that it will take a longer period of time for international students to adapt to their new environment if they are not ready to mix with the Home/local students however; there are chances for the $15.2 \%$ of students in university accommodation to adapt easily with the new culture. The study [14] states the benefits of mixing with Home/local students, such as: having knowledge of where to shop for their groceries, students' discount products, affordable means of transportation, and systems involved with the use of public transportation etc.

This study also identified how these students find it as a challenge to adapt to a new educational system $/$ method in a short period of time. It was not a surprise to see a significant result on the respondents agree to the fact that there is a great deal of coursework which probably is caused by the new system of education that is experienced in their chosen country. This is supported by other relevant studies that identified coursework or modules as a threat to the experience of foreign students [14,22]. Apparently, the system of learning is one of the means by which foreign students can be anxious, thus, affecting their learning performance. Apart from the new educational system, the workload of students is seen as one of the factors that can trigger anxiety and result into having low academic performance or low grades. According to the response of the participants, it indicates that too much coursework can make it difficult for students to focus on their studies. It was a significant result $(\mathrm{p}=0.01)$ when cross tabulated against gender which shows that $63 \%$ of male responded that workload do affect them and increase the level of anxiety; while $36 \%$ of female responded to this; $1 \%$ was missing. [22] reported on the workload and the perceived stress of postgraduate students and their coping mechanisms, also identifying the importance of counselling to improve academic performance and time management.

Social anxiety is also a threat to international students as they are being deprived of their traditional means of support, familiar ways of communicating, and also their lifestyle [14]. According to [24], it is important to understand academic stressors and reaction an individual encounters because they may differ. Thus, ethnicity was measured against students' coping mechanism when stressed; $90 \%$ of Asians prefer to take a walk when stressed and $55 \%$ of Blacks/AfroCaribbean prefers to sleep. This gives the understanding that international students actually depend on themselves to cope with psychological stress instead of sharing their problems with others. [24] reports how difficult it is for students to seek counselling or report their problems when faced with academic pressure. Furthermore, it was argued that female students tends to report their problems than male students because they feel they have ability to cope with their worries by accepting it, not thinking about it or developing a coping mechanism [24]. With the research findings, the use of the counselling team is not significant as many respondents do not rely on counselling the team for advice on mental health. This may be because of the lack of awareness, or the stigma it may bring or their background [25].

Weather in the UK is unpredictable, thus, can impose stress on people in the country. This study [26] reports on the severe weather in the UK that increases mortality rate of older people for over 150years. Many people complain of the unstable weather in the UK, which is quite different from the weather in other countries [27]. It is seen as an important factor that can affect international students coming into the UK. Measuring the change in study pattern caused by weather is very important, although it was not significant when cross tabulated with gender, ethnicity and age but higher percentage of respondents agree with change in weather affecting their study pattern. $54 \%$ of respondents agree that change in weather affects their studies while $46 \%$ were not affected (see Table 2). Out of the $54 \%$ that were affected, $63 \%$ of male and $36 \%$ of females were affected, $1 \%$ was not identified. This study [26] suggests the successive government should concentrate more on indoor warmth to prevent diseases associated with cold weather such as respiratory illness and infections, myocardial infarction and 
thrombotic stroke.

On the aspect of facilities provided by the university library, it implies that facilities present in this university may not have contributed to the anxiety affecting academic performance of students according to our findings. In addition, new technologies and facilities that required high skills may not have been available or experienced staffs may have been provided to guide is students on how to use university library facilities. It important for students to be aware of facilities in the library and its use; this will contribute to their learning experience [2].

Students' level of proficiency in a new country might assist or affect their experience. Students with good language and communication skills might find it easier when transitioning to a new environment with different culture, compared to those of lower skill or level that might find it very or more difficult (see Table 4). This shows that international students may develop more anxiety when they find it difficult to express themselves in English, as a second language learner.

Examination anxiety is identified in this study as one of the factors that might affect students' performance. [28] explains more on the different methods of assessing students, with the preferred method of teaching and communicating in class to reduce the anxiety imposed on them. It is also very important to note that the method of assessment can impose stress on international students, and when there is no confidence while learning, it can affect academic achievement. This also gives the understanding of how important it is for universities to ensure that students gained quality learning experience that will build their confidence for their career aspiration.

\section{Conclusion}

Students are seen as a group that can be easily affected by anxiety which thus, has impact on their academic performances. International students are faced with different challenges that increase anxiety. The Environment in which they live has a lot of influence on them which creates cultural difference, language barrier, discrimination, and differences in educational systems. And all these combined together can have impact on their learning experience and make it not enjoyable. Therefore, mental health of international students have a great impact on their academic achievement, experience during learning at an institution and acculturation experience in their newly found environment, therefore, institutions must invest on students' mental health and see it as an important responsibility to be addressed. Many factors can affect students lived experience such as financial difficulties, academic stress, future prospects; all of these can contribute to the experience of international students. Universities should also take it as a responsibility not only to produce knowledgeable graduates but students that are balanced both mentally and in their chosen course. Although, many research has been done on experience of international students however, few of these research have been specific to a particular anxiety and the major one among international postgraduate students, hence makes the research relevant.

There are some limitations to this study. First, the data collected cannot be generalizable as a true representative of British international University Students. This research may be more beneficial using a large scale study that will reveal the effects of anxiety more. In addition, this study cannot conclude that anxiety is the only emotional behaviour or factor that can cause poor academic achievement. Limitation can also occur due to the method of collecting responses from the participants at one point in time (cross sectional studies) that may create bias. Therefore, future research should cover both undergraduate and postgraduate students to measure the level of stress among these groups and identify the major types of anxiety affecting their academic performance.

\section{Acknowledgments}

The authors wish to appreciate the international postgraduate students of the University of Bedfordshire, Luton Campus for participating in this study. My appreciation also goes to Rev.\& Mrs I. Adeoye for their immersed support during the time of carrying out this research, with Mr. Ogundijo Daniel Agboola for his continued support.

\section{References}

[1] Rienties, B., Beausaert, S., Grohnert, T., Niemantsverdriet, S. \& Kommers, P. (2012) 'Understanding academic performance of international students: The role of ethnicity, academic and social integration', Higher Education, 63 (6), pp.685-700 [Online]. Available at: http://0ehis.ebscohost.com.brum.beds.ac.uk/eds/pdfviewer/pdfviewer ? $\mathrm{sid}=\mathrm{ca} 629543-8 \mathrm{a} 2 \mathrm{~b}-40 \mathrm{a} 0-8 \mathrm{e} 96$ bae $325 \mathrm{~b} 1 \mathrm{~b} 14 \mathrm{~b} \% 40$ sessionmgr $104 \&$ vid $=2 \&$ hid $=109$ (Accessed: 6 September 2013).

[2] Smith, R.A. \& Khawaja, N.G. (2011) 'A review of the acculturation experiences of international students', International Journal of Intercultural Relations, 35 (6), pp.699-713.

[3] Organization for Economic Co-operation and Development (OECD) (2010) Education at a glance 2010. OECD indicators. OECD Publishing.

[4] Jiao, O.G., Onwuegbuzie, A. J. (1999) 'Library anxiety among international students', Educational Resources Information Center (ERIC), 34(2), pp. 1-11

[5] Ramachandran, N.T. (2011) 'Enhancing international students' experiences: An imperative agenda for universities in the UK', Journal of Research in International Education, 10 (2), pp.201-220 Available at: http://0ehis.ebscohost.com.brum.beds.ac.uk/eds/detail?sid=b9627d64 $-4230-4767-9 b 9 \mathrm{e}-$

7b71a1938d8d\%40sessionmgr104\&vid=2\&hid $=102$ (Accessed: 27 June 2013).

[6] Harrison, P. (2002) 'Educational exchange for international understanding', International Educator, 11(4), 2-4. 
[7] Huang, R. (2008) 'Mapping educational tourists' experience in the UK: Understanding international students', Third World Quarterly, 29 (5), pp.1003-1020 [Online]. Available at: http://0 -

ehis.ebscohost.com.brum.beds.ac.uk/eds/pdfviewer/pdfviewer ?sid=124c3272-0f09-4017-8681-

8b414895c50c\%40sessionmgr113\&vid $=2 \&$ hid $=115$

(Accessed: 19 September 2013).

[8] Berry, J.W. (2006) Stress perspectives on acculturation. Newbury Park: Sage

[9] Nadeem, M., Ali, A., Maqbool, S. \& Zaidi, S.U. (2012) 'Impact of anxiety on the academic achievement of students having different mental abilities at university level in bahawalpur (southern punjab) pakistan', International Online Journal of Educational Sciences, 4 (3), pp.519-528 [Online]. Available at: http://0ehis.ebscohost.com.brum.beds.ac.uk/eds/pdfviewer/pdfviewer ?sid=857474a1-db74-4b4c-9408-

1 dd1c90e $9465 \% 40$ sessionmgr12\&vid=2\&hid=15 (Accessed: 12 June 2013).

[10] Gregory, A.M. \& Eley, T.C. (2007) 'Genetic influences on anxiety in children: What we've learned and where we're heading', Clinical Child \& Family Psychology Review, 10 (3), pp.199-212 [Online]. Available at: http://0 ehis.ebscohost.com.brum.beds.ac.uk/eds/pdfviewer/pdfviewer ?sid=dbef5e43-0627-4508-b591-

$71 \mathrm{cb} 4369 \mathrm{db} 23 \% 40$ sessionmgr $115 \&$ vid $=2 \&$ hid $=105$ (Accessed: 13 June 2013).

[11] Hubert, M.D. \& Bonzo, J.D. (2010) 'Does second language writing research impact U.S. university foreign language instruction?', Elsevier, 38 (2010), pp.517-528 [Online]. Available at: http://0www.sciencedirect.com.brum.beds.ac.uk/science? ob=MiamiI mageURL\&_cid $=271757 \& \_u s e r=610894 \& \_p i i=S 0346251 X 1$ 0001107\&_check=y\&_origin $=$ article\&_zone $=$ toolbar\&_cover Date $=2010$-Dec-

$31 \&$ view $=$ c\&originContentFamily $=$ serial $\& w c h p=d G L z V l k-$ zSkzV\&md5=8feb2e106d8c84bf7927507bd0889011\&pid=1s2.0-S0346251X10001107-main.pdf (Accessed: 30 May 2013).

[12] Porte, G. \& Richards, K. (2012) 'Focus article: Replication in second language writing research', Journal of Second Language Writing, 21 (2012), pp.284-293 [Online]. Available at: $\quad \mathrm{http}: / / 0$ www.sciencedirect.com.brum.beds.ac.uk/science?_ob=MiamiI mageURL\&_cid $=272112 \&$ user $=610894 \&$ pii $=$ S106037431 2000379\&_check=y\&_origin $=$ article\&_zone $=$ toolbar\&_cover Date $=2012$-Sep-

$30 \&$ view $=$ c\&originContentFamily $=$ serial $\& w c h p=$ dGLbVlBzSkWz\&md5=c969fc30937612edcee6f51434fd464f\&pid=1s2.0-S1060374312000379-main.pdf (Accessed: 30 May 2013).

[13] Cheng, Y., Horwitz, E.K. \& Schallert, D.L. (2002) 'Language anxiety: Differentiating writing and speaking components', Language Learning, 49 (3), pp.417-446.

[14] Desa, A., Yusooff, F. \& Nor Ba'yah, A.K. (2012) 'Acculturative stress among international postgraduate students at UKM', Procedia - Social and Behavioral Sciences, 59 (1), pp.364-369 [Online]. Available at: http://0-ac.elscdn.com.brum.beds.ac.uk/S1877042812037354/1-s2.0 S1877042812037354-main.pdf?_tid=596afe54-16f2-11e3$8 \mathrm{a} 65-$

00000aacb35d\&acdnat $=1378471769$ 0f032d4c0735c6cb854a 05fb05253231 (Accessed: 6 September 2013).
[15] Kraemer, H.C., Yesavage, J.A., Taylor, J.L. \& Kupfer, D. (2000) 'How can we learn about developmental processes from cross-sectional studies, or can we?', American Journal of Psychiatry, 157 (2), pp.163-171 [Online]. Available at: http://journals.psychiatryonline.org/data/Journals/AJP/3709/1 63.pdf (Accessed: 15 May 2013).

[16] Fife, Department of psychology (2005) Understanding anxiety. Available at: http://www.scotland.gov.uk/Resource/Doc/98780/0023929.pdf (Accessed: 26 June 2013).

[17] Phillips, E.M. (2011) 'The effects of language anxiety on students' oral test performance and attitudes', The Modern Language Journal, 76 (1), pp.14-26 [Online]. Available at: http://onlinelibrary.wiley.com/doi/10.1111/j.1540-

4781.1992.tb02573.x/abstract (Accessed: 16 December, 2012).

[18] University of Minnesota (2013) Taking charge of your health. [Online]. Available

at: http://takingcharge.csh.umn.edu/conditions/anxiety-depression (Accessed: 23 June 2013)

[19] Schweisfurth, M. \& Gu, Q. (2009) 'Exploring the experiences of international students in UK higher education: Possibilities and limits of interculturality in university life', Intercultural Education, 20 (5), pp.463-473 [Online]. Available at: http://0ehis.ebscohost.com.brum.beds.ac.uk/eds/detail?sid=19253a8eabfa-4c2c-a980-

5ce681e $6 \mathrm{cb} 4 \mathrm{a} \% 40$ sessionmgr 104\&vid=2\&hid=102 (Accessed: 27 June 2013).

[20] Gresham, R. \& Clayton, V. (2011) 'Community connections: A programme to enhance domestic and international students' educational experience', Journal of Higher Education Policy \& Management, 33 (4), pp.363-374 [Online]. Available at: http://0-

his.ebscohost.com.brum.beds.ac.uk/eds/pdfviewer/pdfviewer? $\mathrm{sid}=63 \mathrm{e} 9 \mathrm{~d} 6 \mathrm{e} 4-1971-4 \mathrm{c} 6 \mathrm{~d}-\mathrm{a} 1 \mathrm{e} 2$ -

60e54fe $834 \mathrm{c} 6 \% 40$ sessionmgr4\&vid $=2 \&$ hid $=6$ (Accessed: 12 September 2013).

[21] Paltridge, T., Mayson, S. \& Schapper, J. (2010) 'The contribution of university accommodation to international student security', Journal of Higher Education Policy \& Management, 32 (4), pp.353-364 [Online]. Available at: http://0ehis.ebscohost.com.brum.beds.ac.uk/eds/pdfviewer/pdfviewer?s id=69a53093-e393-40ed-b221-

04ad27082367\%40sessionmgr4\&vid $=2 \&$ hid $=6$ (Accessed: 12 September 2013).

[22] Dean, A. (2012) 'Improving the learning experience for international students', International Journal of Management Cases, 14 (1), pp.207-222 Available at: http://0ehis.ebscohost.com.brum.beds.ac.uk/eds/pdfviewer/pdfviewer ?sid $=2 \mathrm{~b} 93 \mathrm{f} 31 \mathrm{~d}-53 \mathrm{c} 1-42 \mathrm{c} 0-9 \mathrm{cc} 2$ -

aaa41074b8c2\%40sessionmgr4\&vid=2\&hid=5 (Accessed: 15 September 2013).

[23] Misra, R. \& McKean, M. (2000) 'College students'academic stress and its relation to their anxiety, time management, and leisure satisfaction', American Journal of Health Studies, 16 (1), pp.41-51 Available at: http://www.biomedsearch.com/article/Collegestudents-academic-stress-its/65640245.html (Accessed: 19 December, 2012). 
[24] Hyun, J., Quinn, B., Madon, T. \& Lustig, S. (2007) 'Mental health need, awareness, and use of counselling services among international graduate students', Journal of American College Health, 56 (2), pp.109-118 [Online]. Available at: http://0ehis.ebscohost.com.brum.beds.ac.uk/eds/pdfviewer/pdfviewer ?sid=e69ef55a-81b7-443a-9755-

06cdda1b9a94\%40sessionmgr113\&vid=2\&hid=109

(Accessed: 6 September 2013).

[25] Goodwin, J. (2007) 'A deadly harvest: The effects of cold weather on older people in the UK', British Journal of Community Nursing, 12 (1), pp.23-26 [Online]. Available at: http://0-

ehis.ebscohost.com.brum.beds.ac.uk/eds/pdfviewer/pdfviewer ?sid $=\mathrm{c} 49 \mathrm{e} 5 \mathrm{c} 30$-ed $8 \mathrm{c}-459 \mathrm{e}-9 \mathrm{e} 1 \mathrm{f}-$

$39 \mathrm{fc} 207 \mathrm{~d} 24 \mathrm{c} 6 \% 40$ sessionmgr 104\&vid $=2 \&$ hid $=105$

(Accessed: 18 September 2013).
[26] Greenwood, N., May, S., Lissouba, P. \& Bithell, C. (2007) 'Widening participation: Accessing careers in the allied health professions', International Journal of Therapy \& Rehabilitation, 14 (11), pp.494-501 [Online]. Available at: http://0

ehis.ebscohost.com.brum.beds.ac.uk/eds/pdfviewer/pdfviewer ?sid=bb8cbdaf-d057-4579-80a6-

ec0adc07ccab\%40sessionmgr115\&vid=2\&hid=110 (Accessed: 8 July 2013). 